\title{
Effect of tillage practices on moisture retention and maize (Zea mays L.) performance under rainfed conditions in Swaziland
}

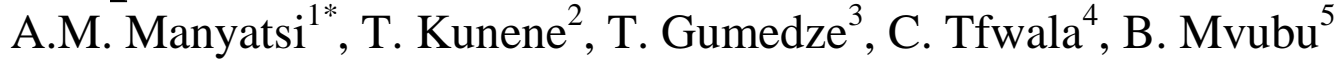 \\ ${ }^{1,2}$ University of Swaziland, Faculty of Agricultulture, P.O. Luyengo, Swaziland, M205 \\ ${ }^{3,4,5}$ Ministry of Agriculture, Malkerns Research Station, P.O. Box 4, Malkerns, Swaziland, M204
}

\begin{abstract}
An experiment was conducted to determine the effect of tillage practices on moisture retention and maize performance under rainfed conditions in Swaziland. The five treatments were based on structure of seedbed and seed planting method. They were; zero tillage where jab planter was used to directly seed (JAB), tractor drawn planter to directly seed without ploughing (TDSS), tractor drawn cultivator to loosen soil followed by planting with tractor planter (TDRDS), planting basics made by using hand hoe (PLB) and conventional tillage (CNT) which was used as a control. The treatments were replicated three times. The data collected included weather data, germination counts, plant height, moisture retention, total dry matter and dry grain yield. The results displayed a significant difference in terms of moisture retention for the majority of the periods where measurements were done ( $p<0.05)$. Conventional tillage retained the least moisture while JAB retained the most moisture. In terms of seed emergence, TDRDS had the highest emergence during the first seven days compared to the other treatments. Conventional tillage had the tallest plants $(268.5 \mathrm{~cm})$ compared to the other treatments at 21 days after planting. Conventional tillage also had the highest total dry matter (16.2 tons/ha) and planting basins had the lowest dry matter (12.6 tons/ha). TDRDS had the highest grain yield (9.9 tons/ha), and JAB had the lowest grain yield (9.1 tons $/ \mathrm{ha}$ ). The difference in mean total dry matter and mean grain yield was not significant $(p>0.05)$.
\end{abstract}

Keywords-Germination, maize, moisture, tillage, yields.

\section{INTRODUCTION}

Maize (Zea mays) is Swaziland's staple food crop and is produced by over $90 \%$ of small holder farmers on communal land [1]. The crop is grown mainly for subsistence purposes. While almost all homesteads in the communal land produce maize, the country has never reached self-sufficient levels in maize production [2]. As a mitigation strategy, the gaps in production are covered by imports from South Africa which is the neighbouring country.

Maize can be grown on a wide variety of soils, but performs best on well-drained, well-aerated, deep warm loams and silt loams containing adequate organic matter and well supplied with nutrients [3]. It can be grown successfully on soils with a $\mathrm{pH}$ range of $5.0-7.0$, but a moderately acid environment of $\mathrm{pH}$ range $6.0-7.0$ is optimum. Values outside this range may result in nutrient deficiency and mineral toxicity. Addition of lime is recommended for good yields on more acid soils.

Availability of moisture in the soil is fundamental for sustainable maize production as maize requires 450 to $600 \mathrm{~mm}$ of rainfall per unit area for optimum growth [4]. The crop evapotraspiration (ETc) for maize is between $1.09 \mathrm{~mm} /$ day and 5.50 $\mathrm{mm} /$ day, with average value being $3.33 \mathrm{~mm} /$ day [5]. Tillage is practiced to loosen the soil, forming a good medium to enhance uniform seed germination, weed management and incorporate crop residues [6]. Retaining permanent soil cover in minimum tillage can reduce water requirement for a crop by as much as 30\% [7]. Subsoil tillage was reported to decrease water consumption by up to $8 \%$ and increase maize yield by up to $674 \mathrm{~kg} / \mathrm{ha}$ compared to conventional tillage [8]. Tillage may result in high crop yields due to modification of soil's physical, chemical and biological properties [9]. The objective of the study was to determine the effect of tillage practices on moisture retention, and maize performance under rainfed conditions in Swaziland.

\section{MATERIALS AND MethodS}

\subsection{Description of the study area and research design}

The experiment was conducted at the Malkerns Research Station in Swaziland, located at $26.55543{ }^{\circ} \mathrm{S}, 31.16293{ }^{\circ} \mathrm{E}$, at an altitude of $752 \mathrm{~m}$ above sea level. The area is in the semi-arid region of the country with long-term average annual rainfall ranging between $800-1000 \mathrm{~mm}$. The soils are sandy clay loam with high mineral content. It was conducted between November 2016 and April 2017.

The experiment was Randomized Complete Block Design (RCBD), with five treatments that were replicated three times. The five treatments were based on the structure of seedbed and seed planting method. The treatments were; jab planter (JAB), 
tractor drawn direct maize seeder (TDDS), tractor drawn tines cultivator \& maize seeder (TDRDS), planting basins (PLB), and conventional tillage (CNT). In the JAB treatment, planting was done directly using hand held jab planter without cultivating the soil [10]. Planting was done using tractor drawn maize seeder without cultivating the soil for the TDRDS treatment. The double row direct maize seeder used was drawn by Landini Powerfarm tractor that weighted $3320 \mathrm{~kg}$ [11]. A tractor drawn tines cultivator was used to loosen the soil prior to planting using the tractor drawn direct maize seeder for the TDRDS treatments. Planting basins with diameter of $25 \mathrm{~cm}$ were made using a hand hoe. Seeds were planted by hand at the centre of each basin. The plots were cultivated using tractor drawn mould board plough in the conventional tillage. There after planting was done by hand. The conventional tillage treatment was used as a control.

Each plot measured $7 \mathrm{~m}$ by $6 \mathrm{~m}$, with 6 rows of maize planted $0.90 \mathrm{~m}$ apart and $0.25 \mathrm{~m}$ between plants. A $5 \mathrm{~m}$ and $2 \mathrm{~m}$ alley was left between the treatments and replications respectively.

\subsection{Planting and fertilizer application and agronomic practices}

Soil samples were taken from the site before planting to determine the soil $\mathrm{pH}$, nitrogen $(\mathrm{N})$ and phosphorus $(\mathrm{P})$ content. The results were used to determine fertilizer requirements. Compound basal fertilizer in the form of Nitrogen $(\mathrm{N})$, Phosphorus $(\mathrm{P})$ and Potassium at ratio of 2:3:2 (22) was applied at a rate of $400 \mathrm{Kg} / \mathrm{ha}$ at planting. This resulted in application of $25 \mathrm{~kg} / \mathrm{ha}$, $38 \mathrm{~kg} / \mathrm{ha}$ and $25 \mathrm{~kg} / \mathrm{ha}$ for $\mathrm{N}, \mathrm{P}$, and $\mathrm{K}$ respectively. Nitrogen in the form of Limestone Ammonium Nitrate (28\% N) was applied some 35 days after planting as side top dressing at a rate of $28 \mathrm{~kg} / \mathrm{ha}$. Planting was done on the $3^{\text {rd }}$ of November, 2016. A hybrid maize variety, SC 719 was used for the trial. The variety is moderately tolerant to heat and drought stress. It takes about 130 days to mature and has a potential yield of 10 tons/ha under optimum conditions. [12].

A combination of CLEAOUT 45 Plus and Dual Gold herbicide was applied to all the plots some 48 hours before planning. CLEAOUT 45 Plus is a non-selective, non-residual herbicide that is used to control herbaceous weeds in agricultural sites [13]. Dual Gold is a selective concentrate herbicide for pre-emergence control of annual grasses [14]. CLEAROUT 45 Plus herbicide and Dual Gold herbicide were mixed with 20 litres of water at a dose of $400 \mathrm{ml}$ and $100 \mathrm{ml}$ respectively. Bladex, a selective herbicide for control of weeds was applied some five weeks after planting at a concentration of $400 \mathrm{ml}$ Bladex in 20 litres of water [15]. The herbicides were all applied using a knapsack sprayer. Bulldock 0,05 GR granular pesticide was used to control maize stock borer (Buseola fusca). About a gram of the pesticide was applied into each maize plant funnel some seven weeks after planting [16]. The experiment was rainfed and no irrigation was applied.

\subsection{Data collection and analysis}

Data collected from the field were; germination count, plant height, total dry matter and dry grain yield. The number of seeds that had emerged was counted in each plot for day 5 to day 9 after planting.. Plant height was measured for 10 plants in each plot using calibrated wooden pole sat 7,9 and 21 weeks after planting. The same plants were used to measure height at all the periods. Five plants were sampled from each plot to determine the total dry matter produced. This was done at 140 days after planting when the crop was ready for harvesting. The plants were cut at the base and cut into pieces (stem, leaves, tassels and cobs). They were oven dried at $105{ }^{\circ} \mathrm{C}$ for 72 hours, and then weighed to determine the dry matter. Five cobs were randomly sampled from each plot. The grain was removed from the cobs when the moisture content was determined to be $12.5 \%$ using a hand held moisture meter [17]. The grain was weighted to determine grain yield from the five plants. The yield from the five plants was multiplied by 8000 to determine yield per ha, where the assumed plant population was 40000 per ha [18]. Moisture retention was determined in each plot during the period of November to December 2016 using soil moisture probe [19] between week 4 and week 9 after planting. The moisture retention was determined at 3 days interval.

Weather data (daily rainfall, minimum air temperature, maximum air temperature and soil temperature) were collected from the adjacent weather station at Malkerns Research Station.

The data collected during the course of the experiment were analysed using the Statistical Package for Social Sciences [20], whereby analysis of variance (ANOVA) was done in order to determine any significant differences between the treatments. The mean separation test was carried out using the Least Significant Difference (LSD).

\section{RESULTS AND DISCUSSIONS}

\subsection{Soil analysis results and weather data}

The soil pH was 5.11 in potassium chloride and in water it was 6.20 with an exchangeable acidity of $0.43 \%$ and delta pH of 1.09 , meaning that there was a net positive charge in the soil. Available nitrogen was $0.14 \%$ and phosphorus $3.85 \mathrm{ppm}$. The 
organic matter content of the soil was determined to be at $2.28 \%$. Lime was not applied as the soil $\mathrm{pH}$ was at the required range. The mean air temperature for the duration of the experiment was optimum as it ranged between $17{ }^{\circ} \mathrm{C}$ and $29.9^{\circ} \mathrm{C}$ (Table 1).

TABLE 1

MEAN AIR TEMPERATURE AND SOIL TEMPERATURE DATA AT MALKERNS

\begin{tabular}{|c|c|c|c|}
\hline \multirow{2}{*}{ Month } & \multicolumn{3}{|c|}{ Temperature $\left({ }^{\mathbf{0}} \mathbf{C}\right)$} \\
\cline { 2 - 4 } & $\begin{array}{c}\text { Mean maximum } \\
\text { air temperature }\end{array}$ & $\begin{array}{c}\text { Mean minimum } \\
\text { air temperature }\end{array}$ & Mean soil temperature at 30 cm depth \\
\hline November & 25.9 & 17.2 & 23.8 \\
\hline December & 28.9 & 17.9 & 26.3 \\
\hline January & 27.2 & 17.7 & 26.2 \\
\hline February & 28.0 & 18.6 & 26.8 \\
\hline March & 28.2 & 17.1 & 25.1 \\
\hline
\end{tabular}

A total of $537 \mathrm{~mm}$ was received, and this was within the range of rainfall required by the maize crop. The rainfall was well spread, as there was at least $5 \mathrm{~mm}$ of rainfall received in each week, except during week 7 and week 21 (Fig 1).

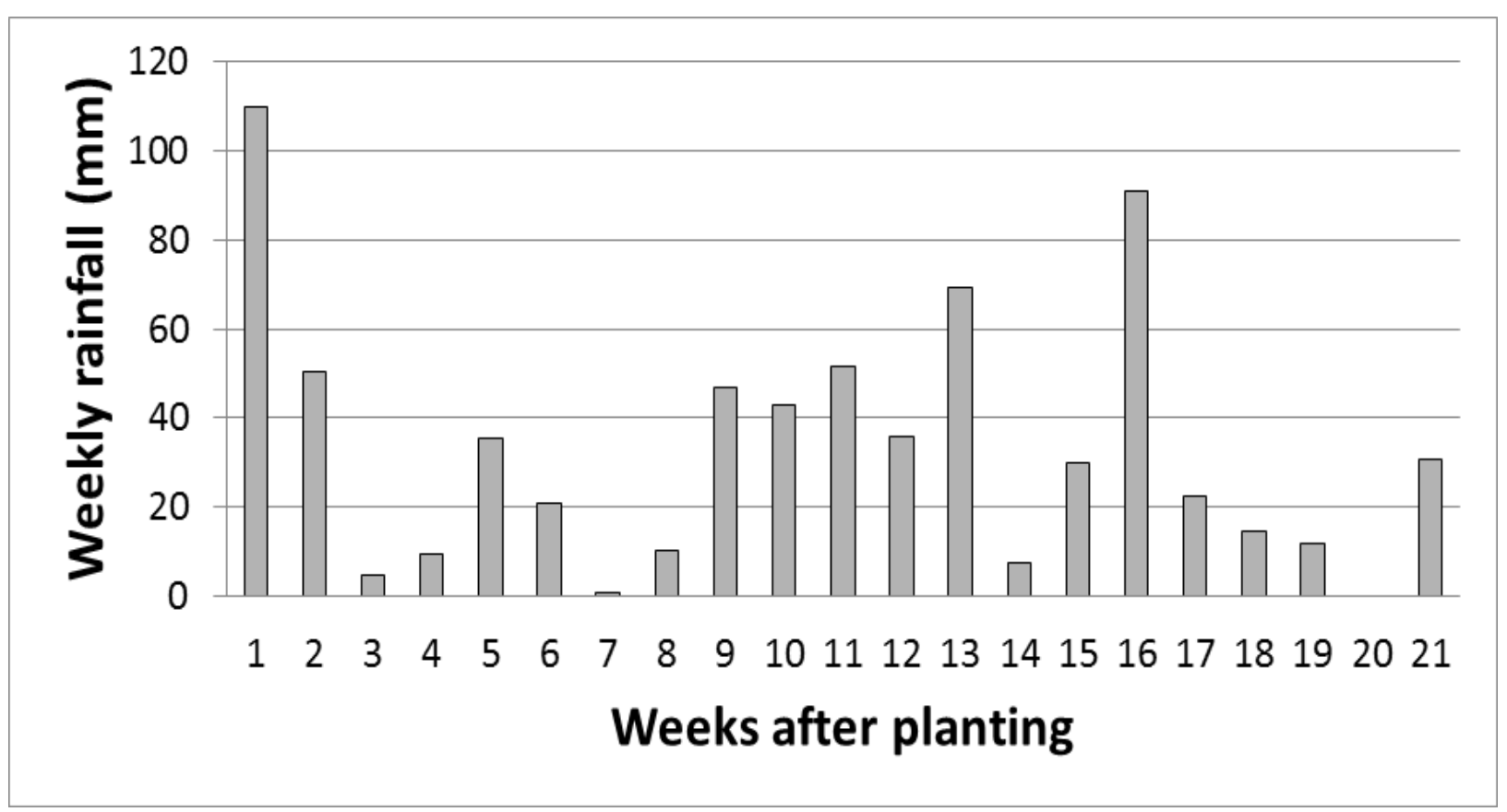

FIGURE 1: WEEKLY RAINFALL RECEIVED DURING THE PERIOD OF EXPERIMENT

\subsection{Soil moisture suction}

Conventional tillage (CNT) conserved the least moisture compared to all the other treatments as shown by the higher soil moisture suction in more or less all the periods (Table 2). The soil suction under CNT was significantly higher than all the treatments during period $1(\mathrm{P}<0.05)$, except for PLB. The moisture suction was measured during the $4^{\text {th }}$ week after planting when cumulative rainfall of less than $15 \mathrm{~mm}$ had fallen within 14 days, and thus the moisture in the soil had been depleted. On the other hand, the soil suctions were lower and not significant different for all the treatments during periods 2,3 and 9. These periods coincided with the weeks when there were high rainfalls and the soil moisture contents were high. The increases in soil moisture retention under conservation tillage were due to decreases in evaporation [21]. Similar results were found in an experiment for selected cowpea varieties where zero tillage conserved about $30 \%$ more moisture compared to conventional tillage [22]. 


\section{TABLE 2}

MEAN SOIL SUCTION FOR DIFFERENT PERIODS (P).

\begin{tabular}{|c|c|c|c|c|c|c|c|c|c|}
\hline & \multicolumn{9}{|c|}{ Mean soil suction during different periods (Centibars)* } \\
\hline Treatment & P 1 & P 2 & P 3 & P 4 & P 5 & P 6 & P7 & P 8 & P 9 \\
\hline JAB & $18.3^{\text {ab }}$ & 4.0 & 10 & $33.0^{\text {abc }}$ & $3.7^{\mathrm{a}}$ & $13.0^{\mathrm{a}}$ & $23.0^{\mathrm{a}}$ & $27.7^{\mathrm{a}}$ & 4.0 \\
\hline TDDS & $21.3^{\text {cd }}$ & 2.7 & 8 & $25.7^{\text {ade }}$ & $7.0^{\mathrm{b}}$ & $14.0^{\mathrm{b}}$ & 28.0 & 35.0 & 2.7 \\
\hline TDRDS & $24.0^{\text {efg }}$ & 2.7 & 9 & $15.0^{\mathrm{bdfg}}$ & $6.7^{\mathrm{c}}$ & 14.7 & 25.7 & 29.7 & 2.7 \\
\hline PLB & $31.7^{\text {aceg }}$ & 3.3 & 8.3 & $29.3^{\text {th }}$ & $4.3^{\mathrm{d}}$ & 17.3 & 25.3 & 30.3 & 3.0 \\
\hline CNT & $33.7^{\text {bdf }}$ & 4.7 & 8.7 & $45.0^{\text {cegh }}$ & $13.7^{\text {abcd }}$ & $20.7^{\text {ab }}$ & $34.0^{\mathrm{a}}$ & $39.3^{\mathrm{a}}$ & 4.7 \\
\hline
\end{tabular}

*Parameters on same column with same symbol indicate that their means were significant different.

\subsection{Maize performance parameters and yield}

The maximum germination count was reached some 9 days after germination, with counts ranging from $83.3 \%$ (under TDDS) to $87.1 \%$ under JAB (Table 3). The differences in means germination counts were not significant ( $p>0.05$ ) for all treatments at 9 days after planting. On the other hand, the germination counts were significantly higher $(p<0.05)$ for treatment TDRDS compared to all the other treatments at 5 days and 7 days after planting. Emergence of seedling is influenced by moisture, aeration and degree of compaction of the soils. The tractor drawn ripper loosened the soil, thus making it easier for the seedlings to emerge. The clods above the seed were pulverized by the cultivator with small weight [23].

TABLE 3

MAIZE SEEDING EMERGENCE FOR DIFFERENT TREATMENTS

\begin{tabular}{|c|c|c|c|}
\hline \multirow{2}{*}{ Treatment } & \multicolumn{2}{|c|}{ Seed emergence (\%)** } \\
\cline { 2 - 4 } & 5 days after planting $^{*}$ 7 days after planting $^{\text {9 days after planting }}$ \\
\hline JAB & $56.1^{\mathrm{a}}$ & $68.5^{\mathrm{a}}$ & 87.1 \\
\hline TDDS & $52.0^{\mathrm{b}}$ & $69.5^{\mathrm{b}}$ & 83.3 \\
\hline TDRDS & $61.1^{\mathrm{abcd}}$ & $75.6^{\mathrm{abcd}}$ & 84.4 \\
\hline PLB & $56.0^{\mathrm{c}}$ & $68.3^{\mathrm{c}}$ & 82.7 \\
\hline CNT & $57.6^{\mathrm{c}}$ & $72.6^{\mathrm{d}}$ & 85.7 \\
\hline
\end{tabular}

*Parameters on same column with same symbol indicate that their means were significant different.

The maize plants were significantly higher for CNT compared to JAB, TDRDS and PLB ( $<<0.05)$ at 7 weeks after planting (Table 4). However the plants were higher for PLB at 9 weeks after planting. At 21 weeks after planting the plants for CNT were higher than in all the other treatments, but the difference in mean height were not significant $(\mathrm{p}>0.05)$. Similar results were observed in a study done in Turkey where plants under conventional tillage were higher than those under no till [24]. In a study done in Ghana there was no significance in difference for mean height between different tillage treatments, even though the shorted plant was found in the no tillage treatment [25]. The great plant height under conventional tillage may be attributed to better soil aeration and more uniform distribution of nutrients in soil profile [26].

TABLE 4

PLANT HEIGHT FOR DIFFERENT TREATMENTS

\begin{tabular}{|c|c|c|c|}
\hline \multirow{2}{*}{ Treatment } & \multicolumn{3}{|c|}{ Plant height (cm). * } \\
\cline { 2 - 4 } & 7 weeks after planting $^{*}$ & 9 weeks after planting & 21weeks after planting \\
\hline JAB & $109.7^{\text {ab }}$ & $194.4^{\text {abc }}$ & 260.3 \\
\hline TDDS & $120.5^{\text {aceg }}$ & $183.8^{\text {adef }}$ & 265.4 \\
\hline TDRDS & $112.1_{\text {cdef }}$ & $179.4^{\text {bdh }}$ & 248.0 \\
\hline PLB & $111.7^{\text {dgh }}$ & $208.2^{\text {ehi }}$ & 266.0 \\
\hline CNT & $122.0^{\text {bfh }}$ & $193.8^{\text {cfi }}$ & 268.5 \\
\hline
\end{tabular}

*Parameters on same column with same symbol indicate that their means were significant different.

Conventional tillage produced the highest total dry matter at 16.2 tons/ha, while PLB produced the least dry matter at 12.6 tons/ha (Table 5). The difference in mean dry matter production for the different treatments was not significant ( $p>0.05)$. On the other hand TDRDS had the highest mean grain yield, at 9.9 tons/ha. The lowest grain yield was realized under PLB 
where the yield was 9.0 tons/ha. The difference in grain yield for all the treatments was not significant ( $\mathrm{p}>0.05$ ). Similar results were realized in Pakistan where the highest dry matter yield was harvested from plants grown under deep tillage, followed by the plants grown under conservation tillage, while the plants grown in zero tillage plots gave the lowest dry matter yield [27]. The same pattern was observed on grain production. A combination of mouldboard plough and disc plough produced the highest grain yield, and no-tillage produced the lowest grain yield in a study conducted in Iran [28].

TABLE 5

TOTAL DRY MATTER AND GRAIN YIELD FOR DIFFERENT TREATMENTS

\begin{tabular}{|c|c|c|}
\hline Treatment & Total dry matter at harvest (tons/ha) & Grain yield (tons/ha) \\
\hline JAB & 14.5 & 9.1 \\
\hline TDDS & 13.8 & 9.6 \\
\hline TDRDS & 15.3 & 9.9 \\
\hline PLB & 12.6 & 9.0 \\
\hline CNT & 16.2 & 9.6 \\
\hline
\end{tabular}

\section{CONCLUSIONS}

The study examined the effect of tillage practices on moisture retention and maize performance under rainfed conditions. Based on the results it can be concluded that the farming season during which the experiment was undertaken received adequate rainfall, as the total received was within the range of rainwater requirement for maize crop. The rains were well spread, and there were no cases of long periods without effective rainfall. CNT conserved the least moisture, as reflected by the higher soil suction values. On the other hand JAB conserved the most moisture. The difference in seed emergence was not significant for the different treatments. However, more seed emergence under TDRDS during the first seven days after planting. It was followed by CNT. CNT produced the tallest plants at 21 days after planting, even though the differences in plant height were not significant. CNT produced the highest dry matter, and PLB produced the least dry matter. PLB also produced the least grain yield. TDRDS produced the highest grain yield, even though the difference in grain yield for the treatments was not significant.

\section{REFERENCES}

[1] FANRPAN (Food, Agriculture, and Natural Resources Policy Analysis Network). Maize Marketing Policy Strategy for Swaziland. http://www.fanrpan.org/documents/dooo22/Maize_Swaziland_Feb2003.pdf. 2016.06.11, 2003.

[2] E.T Titi, Soil tillage in Agro ecosystems. CRC Press, London, 2003.

[3] S.D.M. Magagula, E.V. Dlamini and E.M. Mkhwanazi, Modern Agriculture for Swaziland. Oxford University Press, Oxford, 2007.

[4] J. du Plessis, Maize production. Department of Agriculture, Pretoria, South Africa. 2003. http://www.arc.agric.za/arc-gci/Fact\%20Sheets\%20Library/Maize\%20Production.pdf.2017.07.11, 2003.

[5] C. Zhao and N. Zhongren, Estimating water needs of maize (Zea mays L.) using the dual crop coefficient method in the arid region of northwestern China. African Journal of Agricultural Research, 2 (7): 325-33, 2007.

[6] P.R. Hobbs, K. Sayre and R. Gupta, The role of conservation agriculture in sustainable agriculture. Phil Trans R Soc B $363: 543-$ $555,2008$.

[7] A. Bolt and J. Benites, The importance of soil organic matter, key to drought - resistant soil and sustained food production; FAO Soils Bulleting 80, FAO, Rome, 2005.

[8] Z.Tao, C. Li, Z. Ding, J. Xu, X. Zhou and M. Zhao, Tillage and straw mulching impacts on grain yields and water use efficiency on spring maize in Northern Huang-Huai-Hai valley. The Crop Journal, 3 (5): 445-450, 2015.

[9] M. Farooq, K. Flower, K. Jabran, A. Wahid and K.H.M. Siddique,. Crop yield and weed management in rainfed conservation agriculture. Soil Till Res, 117:172-183, 2011.

[10] Agrotractors, Landini Powerfarm cab. http://argotractors.com/landini/serie_pages/en-ZA/15723/Dimensions.aspx. 2017.5.20, 2016.

[11] African Conservation Tillage Network, Jab planter user manual. http://teca.fao.org/sites/default/files/technology_files/jab\%20planter.pdf. 2017.07.10, 2010.

[12] Seed Co Limited, Maize seed hybrids available in Swaziland and their characteristics. http://seeds.seedco.co/swaziland. 2017.06.10, 2011.

[13] Chemical Products Technologie, Clearout 41 Plus. http://localwisemedia.s3.amazonaws.com/lw_pto/Clear-out-41\%20plus.pdf. 2017.07.10, 2009. 
[14] Syngenta, Dual Gold. Selective Herbicide. 2016. https://www.syngenta.co.za/product/crop-protection/selective-herbicide/dualgold.2017.07.10,

[15] Agnova Technologies, Bladex 900 WG herbicide. http://agnova.com.au/content/custom/products/files/Bladex-herbicide-label.pdf. 2017.07.10, 2016.

[16] Baye, Bulldock 0,05 GR. https://www.cropscience.bayer.co.za/en/Products/Insecticides/Bulldock-1-05-GR.aspx. 2017.06.10, 2016.

[17] Ebay, A2c John Deere grain moisture chek plus tester SW08120. https://www.ebay.com/p/A2c-John-Deere-Grain-Moisture-ChekPlus-Tester-SW08120/1506179209?iid=131434863029. 2017.06.08, 2016.

[18] C. Baloyi, Do row spacing and plant density influence maize productivity under reduced tillage? http://www.grainsa.co.za/do-rowspacing-and-plant-density-influence-maize-productivity-under-reduced-tillage, 2016.11.09, 2014.

[19] Soil Moisture Equipment Corp, 2900F Quick Draw Probe Series. http://www.soilmoisture.com/2900F-QUICK-DRAW-PROBE-SERIES/, 2017.03.20, 2014.

[20] IBM, IBM Statistical Package for Social Sciences (SPSS) Software. IBM Corporation, New York, USA, 2017.

[21] K.P. Fabrizzi, F.O. García, J.L, Costa. and L.I. Picone, Soil water dynamics, physical properties and corn and wheat responses to minimum and no-tillage systems in the southern Pampas of Argentina, Soil and Tillage Research, 81 (1):57-69, 2005.

[22] R.N. Khaemba, J.M. Kinama and G.N. Chemining'wa, Effect of tillage practice on soil moisture retention under three selected cowpea varieties. International Journal of Plant \& Soil Science, 16 (5): 1-5, 2017.

[23] N. Latif, M.A. Khan, and T. Ali, Effects of soil compaction caused by tillage and seed covering techniques on soil physical properties and performance of wheat. Soil \& Environ, 27 (2):185-192, 2008.

[24] A. Sessiz, A. Alp and S. Gursoy, Conservation and conventional tillage methods on selected soil properties and corn (Zea mays L) yield under cropping system in Turkey. Bulgarian Journal of Agricultural Science, 16 (5): 597-608, 2010.

[25] S.H.M. Aikins, J.J. Afuakwa and O. Owusu-Akuoko, Effect of four different tillage practices on maize performance under rainfed conditions. Agriculture and Biology Journal of North America, 3 (1): 25-30, 2012.

[26] T.P. Bennie and F.J.P. Botha, Effect of deep tillage and controlled traffic on root growth, water use efficiency and yield of irrigated maize and wheat. Soil Tillage Research, 7: 85-95, 1986.

[27] S.Q. Memon, M.S. Mirjat, A.Q. Mughal and N. Amjad, Effect of conventional and non-conventional tillage practices on maize production. Pak. J. Agri., Agril. Engg., Vet Sci., 29 (2):155-163, 2013.

[28] M. Rashidi and F. Keshavarzpour, Effect of different tillage methods on grain yield and yield components of maize (Zea mays L.). International Journal of Agriculture and Biology, 9 (2): 274-277, 2007. 